National Solidarity Program operational manual : draft,

December 1,2003

[Ministry of Rural Rehabilitation and Development]

[Kabul] : [[Ministry of Rural Rehabilitation and Development], 2003. 30 p. ; $30 \mathrm{~cm}$.

Running title: "Draft December 1, 2003".

File name gives 11 June 2003 as date of publication.

National Solidarity Program (NSP) - Handbooks, manuals
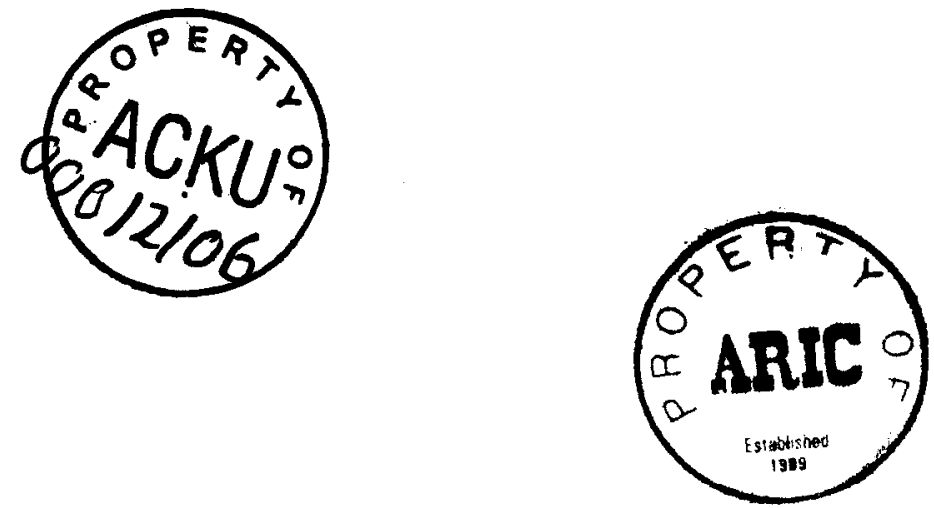


\section{OPERATIONAL MANUAL}

\section{NATIONAL SOLIDARITY PROGRAM}

\section{CONTENTS}

\section{Preface}

I. Introduction
A. Background
B. Goal and Objectives of the NSP
C. Core Elements and Approach
D. Scope and Targeting
E. Conditions for Eligibility and Project Menu

II. Organizational Structure
A. Community
B. The Community Development Council: Roles and Elections
C. Facilitating Partners
D. Ministry of Rural Rehabilitation and Development
E. NSP Steering Committee

III. Cycle of Activities
A Preparation
B. Appraisal
C. Tripartite Implementation Agreement
D. Sub-Project Implementation
E. Monitoring by the Community and Transparency
F. Physical and Financial Progress Monitoring
G. Sub-Project Completion

IV. Fund-Flow and Financial Management
A. Overall Fund-Flow Arrangements
B. Fund Transfer Mechanism
C. Disbursement to Communities
D. Fund Management at the Community Level
E. Financial Management at the Facilitating Partner Level

V. Community Procurement
A. Procurement of Materials
B. Procurement of Services
C. Storage
D. Transport
E. Administrative Costs
F. Savings
G. Transparency

VI. Complaints Processing and Resolution (to be written)

VII. Information and Education Campaign (to be written)

VIII. Training Strategy (to be written)

IX. Monitoring and Evaluation System 


\section{Annexes}

Annex 1 Community Project/Sub-Project Application Form

Annex 2 Appraisal Tool for Sub-Projects

Annex 3

Annex 4

Community Project Approval and MRRD Registration

Annex 5 Appraisal Audit

Annex 6

Annex 7

Tripartite Implementation Agreement

Annex 8

Community Letter Authorizing Representatives to Withdraw Funds

Annex 9

Releases

Community Bidding Forms

Community Sub-Contracting Forms

Annex 10

Annex 11

Sample Review of Tranche Release Recommendations and Payment

Annex 12

Financial Reporting Forms (Community, Provincial and National Levels)

Annex 13

Project Completion Report

Annex 13

Technical \& Financial Audit Form

Annex

Sustainability Monitoring Form

\section{Annex}

Annual Facilitation Partner Assessment Form

Process Monitoring Form

Annex

Quarterly Community Progress Reporting Format (Facilitating Partners)

Annex

Overall Progress Reporting Form (MRRD)

Key Performance Indicator Monitoring Form 


\section{PREFACE}

The National Solidarity Program (NSP) is executed by the Ministry of Rural Rehabilitation and Development (MRRD) with initial funding from the International Development Association (IDA). The NSP Operational Manual provides information on key aspects of the NSP including the project mandate, objectives, institutional arrangements, subproject processes, transfer of funds and financial management, and monitoring and evaluation procedures. The main audiences for the Operational Manual are the staff of MRRD, the national, provincial and district level government officials of other ministries, Facilitating Partners, the Oversight Consultant, and other consultants. The Operational Manual is intended to ensure consistency, transparency, and accountability in the application of project management procedures at all levels. The Operational Manual will be reviewed and revised periodically based on lessons learned from the field. The present version will apply during the first year of implementation till the time that contracts with Facilitating Partners are reviewed for extension. 


\section{INTRODUCTION}

\section{A. Background}

The National Solidarity Program (NSP) has been established by the Government of Afghanistan to develop the ability of Afghan communities to identify, plan, manage, and monitor their own reconstruction and development projects. NSP promotes a new development paradigm whereby communities are empowered to make decisions and control resources during all stages of the project cycle.

The NSP has an implementation framework that includes a methodology for providing direct financing to communities; transparent election procedures for community institutions; and community management of reconstruction and development. This methodology focuses on fostering a commitment to pursuing the development and strengthening of inclusive community institutions through participatory planning and resource management.

\section{B. Goal and Objectives of the NSP}

The NSP aims to lay the foundations for a long-term strengthening of local governance, to make it more inclusive, and to provide assistance for reconstruction and development of communities. This primary aim will be achieved through universal suffrage of representative community development councils, that will regularly consult amongst themselves and with the community at large regarding development needs and priorities, and through this process will manage and monitor of the use of their development resources, and interface with and coordinate activities of outside agencies.

The NSP grants to villages are intended to act as a catalyst in this process, and at the same time provide much needed support for local reconstruction and development activities.

\section{Core Elements and Approach}

The design of NSP consists of four core elements:

- facilitation at the community level to assist communities establish or strengthen inclusive community institutions through elections, reach consensus on priorities and corresponding project activities, develop eligible proposals that comply with NSP appraisal criteria, and implement approved project proposals ;

- a system of direct block grant transfers to support the rehabilitation or development activities planned and implemented by inclusive elected community institutions;

- a series of capacity building activities to enhance the competence of communities (both men and women) for financial management, procurement, technical skills, and transparency that demonstrates the value of equitable collaborative action; ${ }^{1}$ and,

- activities linking local institutions to government line ministries and aid agencies with available services and resources.

The participatory planning process of NSP project activities constitutes in itself a capacity building exercise with regard to inclusive consultation and planning in the community. 
Quality of process is essential for the long term sustainability of community investments and for the success of a program like the NSP. As such, community level planning must follow an approach that complies with the basic principles below:

- participatory planning of activities through inclusive community meetings and representative development councils;

- community contributions to capital costs and operation and maintenance;

- transparency and accountability of budgeting and accounting.

The goal of this approach is to ensure that communities are able and inclined to institute a broad based inclusive decision-making system (which includes women as well as members from marginalized sections of the villages) based on elected development councils and community meetings. Through this process the communities will acquire or strengthen the skills and attitudes necessary to enhance their capacity to define, manage and govern their development with regard to both locally mobilized and externally provided resources. To achieve this goal, the role of the Facilitating Partners (FP) and the NSP will be to create an enabling environment through facilitation of inclusive community elections, community planning, technical assistance, and timely release of funds, which will make possible for the communities themselves to take a lead in planning and managing their development projects.

\section{Scope and Targeting}

In the first year, three target districts in each province has been selected by MRRD. The selection of districts has been based on vulnerability data in terms of severity of drought impacts and number of Internally Displaced Persons (IDPs) and refugees. Inputs from provincial governors and Provincial Administrative Councils will also be sought before district selection is finalized and NGOs are contracted. ${ }^{2}$

During year 1 of the NSP, the program will operate in a selected batch of village communities in the selected districts, and operations will be expanded in year two to cover the remaining villages in the districts, if any, and/or expand operations to new districts. In year 1 , the amount allocated per district will be up to US $\$ 1.6$ million, to be divided among communities with a total population comprising around 8,000 families. ${ }^{3}$ Communities will be defined on the basis of existing local settlement patterns. ${ }^{4}$ Since settlement patterns and the size of villages vary considerably between and even within districts, the resulting number of target villages will vary from district to district. ${ }^{5}$ The identification in selected districts of a cluster of target villages with an aggregate population of up to 8,000 families will be undertaken by the Facilitating Partner. In year 2 , operations will expand to a new set of communities with consideration of logistics and optimal use of field staff. Funds will be allocated for community project proposals that have been appraised by the NSP as meeting the eligibility criteria of the NSP program (See Section E below), and for which implementation agreements have been signed between the NSP and the community organization.

2 In addition to information about the NSP approach and rules, local authorities including the governor, provincial (vilayat) district (woluswali) and sub-district (alakadart) authorities will be kept informed about the progress of the program, and will be expected to provide assistance as needed regarding the overall security for Facilitating Partners and other program staff.

3 In case the number of villages the selected district have a smaller aggregate population than 8,000 families, year 1 operations should be extended into a neighbouring district with a high vulnerability rating in terms of drought impacts and IDPs/refugees.

$4 \quad$ Other available information such as the list of communities/villages prepared for nomination of members of the 2002 Loya Jirga can also be used to identify communities.

$5 \quad$ Villages chosen for annual implementation coverage should to the extent possible be more or less adjacent to facilitate optimal utilization of facilitation staff and transport resources. 
The definition of a village community for the purposes of block grant allocation will be based on three principles:

- A community is a village of more than 50 families; ${ }^{6}$

- One Development Council will be established for each community. Development Councils can not be established for sub-sets of an existing village (e.g. a village can not be split into its constituent political or ethnic/ qaum sub-divisions);

- One block grant (budget) will be allocated to each community at a rate of US\$200 per family with an upper limit of US $\$ 60,000$ per community. This allocation requires that the community develops one or more eligible project proposals within the framework of the block grant allocation and its own contributions.?

A family is defined as a nuclear family consisting of a man, his wife (or wives) and unmarried childre $n$, or a widow(er) and her/his unmarried children. The number of families in the targeted village communities will be assessed by the Facilitating Partner, and this enumeration should be verified through such means as a community meeting, consultations with the local mullah(s), and existing village lists for voluntary contributions towards ashar, mosque repair etc. Once village selection is confirmed (the community will have to confirm its interest to participate during a mass meeting) and the number of families is agreed, the block grant amount would be adjusted to reflect the more accurate population size, and communicated to the community.

As stated above, the minimum size of a community potentially eligible for a block grant allocation would be 50 families. Smaller settlements should be encouraged to join with other ones to pool their block grant allocations for larger scale joint activities (e.g. a clinic, a school, or a multi-village pipe water supply system). Where this is not possible, isolated settlements below 50 families can be exceptionally included.

The block grant of a community can be carried forward to the next year if it has not been fully committed or disbursed for specific projects during Year 1. It can only be carried forward from once from Year 1 to Year 2. Following this single extension, the uncommitted amounts will be cancelled. To help ensure proper oversight of overdue projects, the facilitating partner will monitor and report to the NSP in its quarterly progress reports on tho se subprojects that are significantly behind completion relative to agreed milestones.

An option to facilitate re-integration of IDPs and returning refugees, is to communicate to specific villages with a considerable IDP/refugee population, that the block grant allocation can be increased upon the return of IDPs/refugees and their participation in project planning. This incentive could encourage villages with a high proportion of IDPS or refugees to initiate consultation with them about their return during the project preparation phase to obtain access to an increased block grant allocation. Where a return of IDPs/refugees is planned, and IDPs/refugee families or family members return to their village during the project preparation phase, a reassessment of the population size should be undertaken prior to final project development and costing to enable an adjustment of the block grant allocation. Where such planning is undertaken, the Facilitating Partner should assist the community in assessing whether the additional resources provided through the enhanced block grant and the proposed project activities would enable a sustainable re-integration of the returnees.

6 Exceptions to this rule may be considered on a case by case basis for areas with a dispersed settlement pattern, where habitations are typically smaller than 50 families, and where joint project activities by two or more habitations are not feasible.

The available funding can be expanded, if a community is able to access additional funding from other programs. However, this would not eliminate the requirement for a community contribution of minimum $10 \%$ estimated monetary equivalent of the NSP block grant funding received. 
It is expected that all Facilitating Partners will engage female facilitation staff, and develop arrangements in consultation with the community for the involvement of women during the subproject cycle. Thus, mechanisms for consultation with women's groups, getting their input when prioritizing needs and developing project proposals, selecting officials, etc. should be described in the community development plan (Annex 1$)^{8}{ }^{8}$

\section{E. Conditions for Eligibility and Project Menu}

In order to make use of the block grant allocation, the community must develop an eligible project proposal (or proposals) that fulfils the following criteria (Annex 1):

(i) is proposed by a representative Development Council (which has been elected through a community-wide process),

(ii) is endorsed through an inclusive community-wide process,

(iii) provides equitable access to benefits,

(iv) is technically and financially sound,

(v) includes an operation and maintenance plan,

(vi) has at least $10 \%$ community contributions in estimated monetary equivalent towards capital costs and full responsibility for operation and maintenance,

(vii) includes a commitme nt to and plans for ensuring transparency of the use of block grant funds.

The community contribution towards capital costs can comprise cash, labor, or in kind contributions such as construction materials and transport. ${ }^{10}$ The requisite community contributions in estimated monetary equivalent for each project milestone must be clearly specified (e.g. the amount of labor or materials to be provided at specific stages during implementation). The Facilitating Partner will monitor, assess and report quarterly to the NSP as to whether this condition is being adequately met.

Once it is determined through an appraisal of the project proposal (Annex 2 and Section III.B) by NSP that the eligibility criteria listed above have been complied with, the funds will be paid directly from the NSP to a community, according to defined payment schedule based on the Implementation Agreement (see Chapter IV and Annex 5). The result of the appraisal of the community project proposal will be confirmed in an Approval Letter from NSP. In the case of approved proposals, this letter will include a registration of the Development Council with MRRD (Annex 3).

NSP will use an open menu of subprojects within four types of investments, subject to a short negative list. The four types of investments are ${ }^{11}$ :

- Community infrastructure (the investments will comply with defined technical standards and unit costs, and will only comprise public goods $)^{12}$;

8 NSP will monitor the involvement of women in decision-making regarding the selection of project activities, and as direct project beneficiaries. If findings by the middle of year 1 suggests that their involvement and ability to benefit directly from NSP is limited, alternative op tions will be considered. One such option could be to make an additional (smaller) block grant allocation that can only be used for activities identified by and benefiting women. Another option would be to reserve a certain proportion of the block grant for activities identified by and benefiting women.

9 In the case of facilities such as drinking water supply or small-scale irrigation schemes, the community would be fully responsible for bearing the O\&M costs, whereas facilities such as schools and clin ics are likely to involve funding of recurrent costs in part or fully by the concerned line ministry.

10 The time spent by members of the Development Council will not be counted towards the community contribution, and can not compensated out of the block grant. If the community decides that members of the Development Council should be compensated for their time, this should be from a community contribution over and above the $10 \%$ contributed towards the capital costs of projects.

11 Investments in income generating assets, if later included in the menu, would draw on best practice lessons from other projects. 
- Human capital development activities (e.g., time -bound literacy classes, hygiene education etc., that are not planned to incur recurrent costs from the state);

- self-help savings and credit schemes for women and disabled (this new practice would draw on best practice lessons from other projects and will be based on a pre-defined methodology developed by NSP);

- asset transfers for vulnerable women and disabled (this new practice would draw on best practice lessons from other projects and will be based on a pre-defined methodology developed by NSP).

The project will not fund:

- equipment or materials that are included in the annual implementation plans by other agencies (e.g. by other government or NGO projects that are operating in the area);

- political campaign materials or donations in any form;

- weapons including (but not limited to), mines, guns and ammunition;

- chainsaws;

- pesticides, herbicides and other chemicals; ${ }^{13}$

- investments detrimental to the environment;

- motorized extraction of groundwater, ${ }^{14}$

- land (purchase or lease), under any conditions;

- construction, rehabilitation, or maintenance of any government office buildings;

- payments of salaries to government servants or the salaries of the staff of government subsidized organizations;

- any activity on land that is considered dangerous due to security hazards or the presence of unexploded mines or bombs;

- any activity on land or affecting land that has disputed ownership, tenure or user rights. ${ }^{15}$

- any activity that will support drug crop production or processing of such crops.

As part of promoting technical soundness, each activity must take into account environmental and social impacts as defined in the government's Environmental and Social Safeguards Framework (Annex -). Since most of the works are expected to be small community-based projects, environmental risks are generally considered to be limited. To ensure compliance with the safeguards framework, all proposals must include completed simple environmental and social checklists developed by NSP, which describe impacts and mitigations measures, if any (see Annex 1).

Forced (involuntary) resettlement caused by land acquisition is not allowed under any condition. Any activity that in any way involves voluntary resettlement requires an early

12

Such infrastructure projects would include, but not nccessarily be restricted to irrigation works, roads including culverts and small bridges, erosion protection, structures promoting watershed management, water supply facilities, school buildings and clinics. In case school buildings and clinics are proposed by the community, endorsement would be required from $\mathrm{MoE}$ or $\mathrm{MoPH}$ that that these are included in the development plans of the ministries, and that funding of operational costs would be provided (fully or with community contributions).

13 Exceptions may be considered based on an assessment by the NSP (with specialized consultant assistance, if required, and after no objection from IDA) in special situations such as eradication of infestations of locusts or sen pest.

14 Indiscriminate installation of irrigation wells using motorized extraction of ground water have in some areas contributed to low er the ground water tablc, and constitute a threat to the traditional sustainable irrigation by karez. Until water resource assessments of a particular catchment area or basin has been undertaken and has established that irrigation is feasible, investments in motorized irrigation wells is not permitted.

${ }_{15}$ Thus, investments involving an expansion of the command area of an irrigation system can only take place with agreement from the owners (or users in case of tribal common land) of the land brought under new irrigation. 
special approval from the NSP. The negative list will be reviewed and if necessary revised by NSP every year.

\section{ORGANIZATIONAL STRUCTURE}

\section{A. Community}

For the purposes of the NSP, a community is defined as a village consisting of at least 50 families, who are able to identify a need and come together to access NSP funds. Communities will be identified on the basis of existing local settlement and social patterns. However, this would not prevent different distinct villages, whether small or large, from joining together to develop assets (e.g. a school, a pipe water system, or a road) that serves more than one village. In such a situation, people from all areas that make direct use of the asset should be included as part of the community for the purposes of the planning, implementation, and maintenance of the joint asset.

While a community will be assisted by NSP financially, a key characteristic of this approach is that it promotes a high level of community participation and ownership during all phases of the project cycle. As such, functions of the community will include:

- Electing a Community Development Council;

- Identifying and prioritising needs through community meetings that include both men and women;

- Preparation of a Community Development Plan and sub-project proposals; ${ }^{16}$

- Providing community contributions;

- Participating in field appraisal, project launch ceremony, and all other community meetings related to the project;

- Management of project implementation by the community through its Community Development Council or Project Management Committee(s);

- Providing oversight of project implementation with regard to quality and use of funds;

- Maintaining the asset after completion with community cost contributions.

\section{B. The Community Development Council: Roles and Elections}

The Development Council will be a community-based decision making body which is elected by the community through elections based on a secret ballot. As the representative body of the community with regard to the NSP, the Development Council will be responsible for overseeing the preparation of the Community Development Plan (defining community needs and priorities, and the project or sub-projects to address some or all of these priorities), and the preparation and implementation of individual sub-projects. The Development Council should at least comprise a Chairperson, Treasurer and Secretary. The Development Council should obtain the endorsement through community meetings regarding decisions on rehabilitation or development priorities, the final selection of project proposals developed on the basis of agreed priorities, the size and composition of community contributions, the use of project funds, transparency arrangements, and the arrangements for maintenance of completed projects.

16 With assistance from the Facilitating Partner, the community should develop an overall plan for reconstruction and/or development - the Community Development Plan - listing agreed priorities and projects to address these. Among the list of projects in the Community Development Plan, one or more would be developed as a Sub-Project Proposals for funding from the NSP block grant. Other activities on the priority list can be proposed for funding under the (smaller) Year 2 block grant, or may attract funding from other programs. 
The Development Council will sign an overall Implementation Agreement (Annex 5) with NSP and the Facilitating Partner on behalf of the community. Depending on the number of subprojects to be managed, smaller Community Project Management Committees may be established to prepare and manage individual subprojects, but they will report to the Development Council and the village wide meetings. On the other hand, if a community chooses to implement only one or two subprojects, the Development Council may manage implementation of those projects. These representative Development Councils must be registered with NSP as a condition for receiving assistance and overseeing the management of communally owned property (Annex 3). A Community Project Management Committee (which can be identical with the Development Council and should comprise at least a Chairperson, Secretary, Treasurer, and Storekeeper) nominated by a community wide assembly will be able to withdraw funds and procure goods and services for implementation of the project after being registered with the NSP (Annex 6).

Specifically, the Development Council will be responsible for:

- Overseeing preparation of the community development plan;

- Convening community wide meetings;

- Overseeing planning and preparation of individual subprojects either directly or through community project management committees;

- Mobilizing community contributions;

- Ensuring community participation during all phases;

- Presenting the subproject plans at appraisal;

- Managing and supervising subproject implementation; 17

- Overseeing (or directly handling) procurement and financial management at the community level;

- Reporting to the community and to NSP on project progress and use of funds.

The Community Development Council will be established through an election which will be conducted according to the following rules:

- Everybody in the community who is entitled to vote in government elections is entitled to be registered as a voter;

- Each person has one vote;

- The voting will be conducted through a secret ballot;

- Both men and women are eligible to be members of the Community Development Council;

- Candidates and electioneering is prohibited; and

- At least $40 \%$ of eligible voters to have voted.

Development councils elected under an election that does not comply with these rules will not be eligible for funding under the NSP.

In the case of the first point, registering as a voter is an entitlement, not an obligation. However, in declaring whether the election for the Council is valid (i.e. whether a quorum has been met, see below), an estimate of all eligible voters, not all registered voters should be used. Whether the community wish to extend voting entitlements to people who are not eligible to vote in government elections is a matter for the community to decide.

In the case of the secret ballot it is essential to remove, or at least minimise the opportunity for undue influence to be exerted when people are voting. The exact 
mechanism will need to be determined on a case-by-case basis, but the underlying principle is that each individual should cast his or her vote in private. ${ }^{18}$

Prohibition of candidature and electioneering is critical to reduce the likelihood of elite capture and intimidation, recognising that it will not remove it. To avoid the problem of selecting unwilling candidates, prior to the election, community members will have an opportunity to declare that they are not prepared to accept the position if elected. All members of the community are candidates until they take the positive step to declare themselves ineligible.

Combining high levels of illiteracy and the prohibition of candidature and electioneering will present a range of challenges to implementing partners. However, both aspects are so central to the program that innovative and creative solutions will need to be developed. However, as the elections will take place in small clusters of households many of whom know each other, such solutions are possible. An obvious one is for the implementing partner to assist the illiterate members of the community. An alternative is to prepare ballot papers in the forms of maps of the village, with people marking the address of the person that they wish to vote for and a symbol for the person within that address (eg distinct symbol for oldest male, oldest female, etc).

In order to have functioning Development Councils, the number of representatives should be between 5 and 15 persons depending on the size of the community. The Development Councils should select a Chairperson, Secretary and Treasurer. For the Development Council to have the authority to make decisions over resources it must also have a quorum of the village involved in the election. For the first round of NSP, a quorum is defined as $40 \%$ of all eligible voters. It is government policy to increase this percentage over the life of the program. In cases where it is not possible to register women voters, the number of eligible voters will be calculated by doubling the number of eligible male voters.

Where local norms regarding Purdah does not allow women to participate directly in community wide meetings or in the Development Council, the Facilitating Partner must promote the establishment of a separate forum where women can define their priorities. The Facilitating Partner should also ensure that the priorities defined by women are discussed with the men, and that those defined by the men are discussed with the women, so that the Community Development Plan takes account of both.

To ensure inclusiveness in terms of different socio-economic, factional, and ethnic/tribal (qaum) sub-divisions within the community, the election process should be based a division of the community into groups of families (clusters), which will each elect one representative for the Development Council. Since neighbours are usually also relatives, the division into clusters will also reduce purdah restrictions on women and thereby facilitate their active involvement in discussions of the qualities required for representatives and in the election itself. The size of such clusters will vary depending on the size of the village, but should not exceed about 20 families. The clusters would in turn serve as the framework for community wide consultations on proposals from the Development Council, through a process where the elected councillors consult with and seek feed-back from their electorate before decisions on priorities, sub-projects, and community contributions are finalized.

18 This could involve separate ballot boxes for men and women, decisions on whether the ballot paper will have a list of all interested eligible cluster members, or whether the name of the candidate for which a vote is cast is written on the ballot paper. If either of these solutions are agreed, assistance would have to be provided to illiterate voters by the Facilitating Partner, and a process to verify votes cast on a sample basis would also need to be agreed. Another issue that may require different local solutions, is whether the names of women can be listed on ballot papers, and where this is not possible, how the number of eligible women vot ers is established, and how votes are cast for female candidates. 
Since communities will only have one Development Council, local solutions should be agreed for large villages ( $>300$ families) with assistance from the Facilitating Partner. One such solution could be a two-tier voting process, where candidates elected by clusters of 20 families elect a smaller Development Council.

\section{Facilitating Partners}

Facilitating Partners are agencies (mainly Afghan and international NGOs) contracted by MRRD to assist in the delivery of the NSP to communities. The primary role of the Facilitating Partner is to facilitate an inclusive community planning process to reach consensus on priorities and project proposals, assist the community develop eligible proposals that comply with NSP appraisal criteria, and assist the community with regard to its implementation of approved project proposals.

The Facilitating Partner will report to the NSP. An Implementation Agreement will be signed with the community on the community development plan regarding the exact inputs to be provided and services to be performed by the Facilitating Partner (see Annex 5).

In each province one or more Facilitating Partners will deploy community facilitators and tech nical specialists for three districts at a time to cover target communities with a total of 24,000 families per province per year. Depending on capacity, individual Facilitating Partners will undertake these activities in one or more districts, or in one or more provinces.

A Facilitating Partner is expected to recruit and deploy female field staff to enable involvement of women in the targeted communities in the prioritization, decisionmaking, and implementation of projects.

The roles of the Facilitating Partners are to:

- Facilitate inclusive elections of Community Development Councils;

- Facilitate inclusive community project planning to strengthen community institutions;

- Provide technical assistance to develop sub-project proposals for appraisal through either:

- facilitating community access to technical assistance available in the market or from other agencies; or,

- technical assistance provided by the Facilitating Partner, ${ }^{19}$

- Provide technical assistance to communities during implementation;

- Provide tra ining to communities (e.g. book-keeping, procurement, contracting);

- Conduct monitoring and reporting.

The expected outputs of the Facilitating Partners are:

- Eligible project proposals (measured by the number of projects appraised and approved by the NSP);

- Implementation of funded projects (measured by the number of projects completed in accordance with design standards and in a sustainable manner);

The amount allocated per district in year 1 will be US $\$ 1.6$ million, to be divided among communities with a total population comprising around 8,000 families, equaling an

19 While the preferred approach under NSP is for communities to avail themselves of technical assistance for project design through the market, it is recognized that this may not be feasible in many rural areas, and that in such situations, technical assistance will have to be provided by the Facilitating Partner. 
allocation of US $\$ 200$ per family. Depending on the number of districts defined in the Facilitating Partner's contract, performance will be assessed against the annual target outputs for year 1 as defined in the table below. Achieving or exceeding the year 1 targets will be a key determinant for extension/expansion of the contracts of the Facilitating Partners.

\begin{tabular}{|l|l|l|l|l|l}
\hline District & $\begin{array}{l}\# \text { of } \\
\text { communit } \\
\text { ies }\end{array}$ & $\begin{array}{l}\# \text { of } \\
\text { families }\end{array}$ & $\begin{array}{l}\text { Appraised } \\
\text { and } \\
\text { approved } \\
\text { project } \\
\text { proposals }\end{array}$ & $\begin{array}{l}\text { Completed } \\
\text { projects } \\
\% \text { of funded } \\
\text { projects } \\
\text { completed })\end{array}$ & $\begin{array}{l}\text { \% of sub- } \\
\text { projects } \\
\text { functioning 3 } \\
\text { months after } \\
\text { completion }\end{array}$ \\
\hline $1^{\text {st }}$ batch & $\mathrm{X}$ & $\mathrm{X}$ & $80 \%$ & $80 \%$ & $80 \%$ \\
\hline $2^{\text {nd }}$ batch & $\mathrm{X}$ & $\mathrm{X}$ & $80 \%$ & $70 \%$ & \\
\hline $3^{\text {rd }}$ batch & $\mathrm{X}$ & $\mathrm{X}$ & $60 \%$ & $0 \%$ & $80 \%$ \\
\hline $\begin{array}{l}\text { Aggregate } \\
\text { target }\end{array}$ & $\mathrm{X}$ & 8,000 & $75 \%$ & $75 \%$ & \\
\hline
\end{tabular}

The table above assumes that the Facilitating Partner's staff is deployed so that facilitation of project preparation and implementation in a district is undertaken in three successive batches, each with a four month period for community planning, project preparation and appraisal, followed by an implementation period depending on the type of project that is undertaken. The table reflects, that some of the target communities in the $3^{\text {rd }}$ batch would still be in the process of project preparation and appraisal by the end of year 1, and that implementation, if started, would not be completed. Likewise, for some of the target communities in the $2^{\text {nd }}$ batch, ongoing implementation would not be completed by the end of year 1 . Since not all Facilitating Partners may choose to deploy their field staff for coverage of their annual target as outlined above, an aggregate target is provided for expected outputs in a district in year 1 .

The NSP will hold Facilitating Partners accountable for performance against outputs, but the NSP will provide flexibility to its partners in the choice of specific facilitation methods and work planning. The Facilitating Partners may use facilitation methods that they deem appropriate in order to achieve the outputs (the criteria) against which the eligibility of community project proposals will be appraised (see Section I.E above), and may also plan the deployment of their staff and sequencing of activities in ways they consider optimal for achieving their overall output targets.

\section{Ministry of Rural Rehabilitation and Development}

MRRD will be responsible for overall management and supervision of the National Solidarity Program (NSP). Within the ministry, the NSP will Oversight Consultant will, and will be managed by an Oversight Consultant working with MRRD counterparts to strengthen capacity for community development and program management in MRRD. Hereafter, when reference is made to MRRD or NSP staff, this means the Community Development Department and its provincial representatives including staff from the Oversight Consultant. The Community Development Department will:

- manage the NSP block grants for community projects (including effecting fund transfers, tranche payments, financial management, and accounting);

- supervise the performance of Facilitating Partners (including contract management, contracting of Facilitating Partners beyond those recruited by MRRD prior to the Oversight Consultant being recruited in order to secure services of Facilitating Partners to cover all 32 provinces at the scale required);

- Appraise community project proposals;

- plan and conduct training for the field staff of Facilitating Partners (either directly or through sub-contracting); 
- undertake technical and financial monitoring, and produce consolidated progress reports, and

- manage an information and communication campaign.

\section{E. NSP Steering Committee}

The Steering Committee will act in an advisory capacity to the NSP on overall policy formulation and direction, and oversee program implementation. Specifically, it shall develop policies that shall lead to the effective management of the NSP program. Policies developed will conform with the objectives of the Government of Afghanistan and the provisions of the agreements between the Government and IDA.

Membership in the Steering Committee will include representatives from the Ministry of Rural Rehabilitation and Development, the Ministry of Finance, and other stakeholders selected on the basis of criteria yet to be determined.

\section{NSP ORGANIZATIONAL SET-UP}

National Level
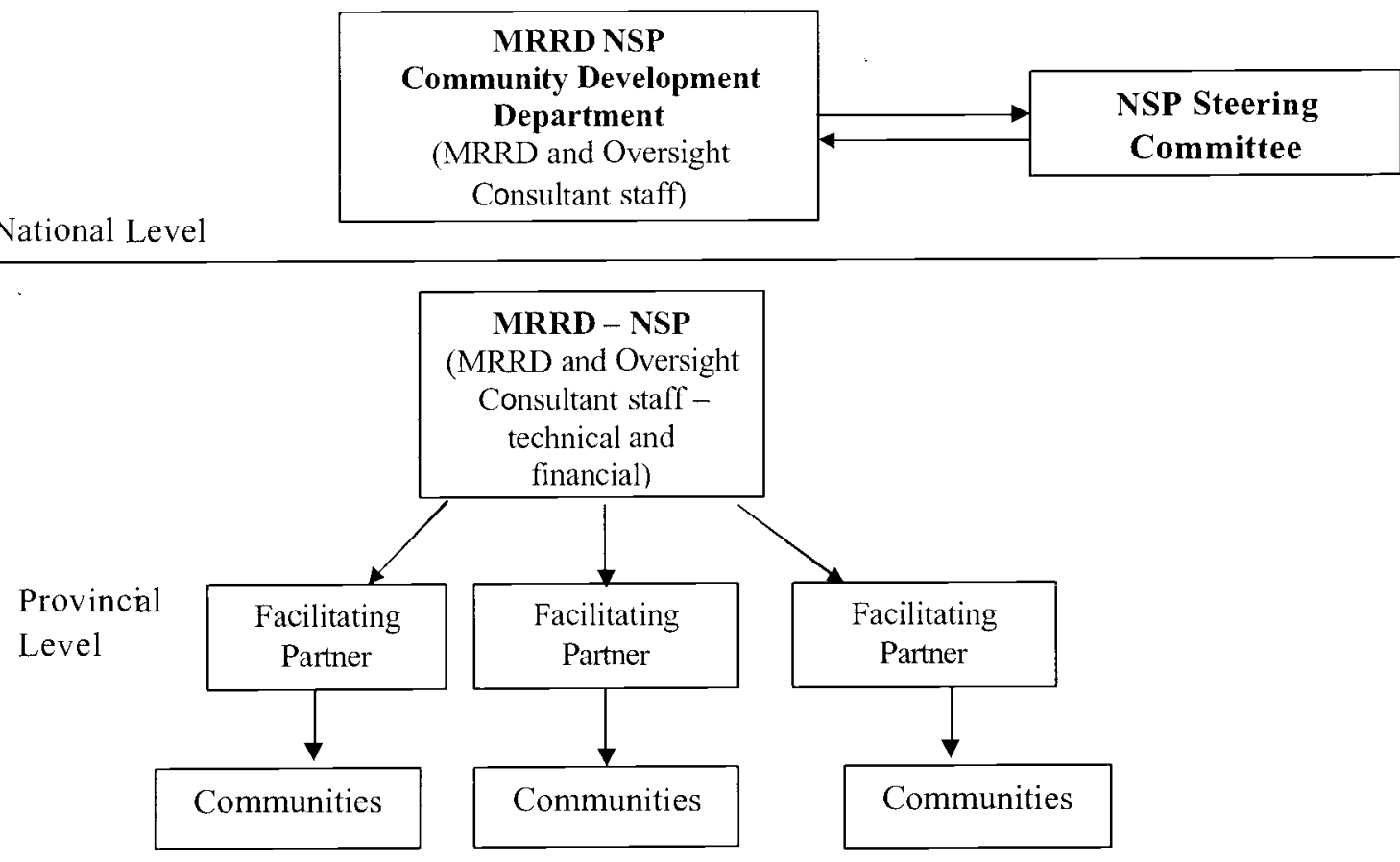


\section{CYCLE OF ACTIVITIES}

This section covers the activities to be undertaken during preparation, appraisal, implementation and completion of the subproject cycle. The goal is to facilitate an inclusive participatory process within the community which results in an equitable community development plan comprising one or more subprojects that are eligible for funding under the NSP and/or eligible for funding from other existing programs. The long-term goal is the creation of community institutions that are the expression of the community's ability to mobilize, consult, plan, finance, implement, and evaluate its own development.

\section{A. Preparation}

During this phase of the cycle, Facilitating Partners will help to:

- mobilize the community including facilitation of community meetings and the establishment through elections of a community Development Council, and of related project management committees as agreed with the community;

- facilitate an participatory planning process that includes women and the weaker sections of the community;

- strengthen community capacity to identify and prioritise needs;

- facilitate the preparation of a Community Development Plan and proposals for specific project(s) with budget(s);

- provide technical assistance to develop sub-project proposals for appraisal through either:

- facilitating community access to technical assistance available in the market or from other agencies; or,

- technical assistance provided by the Facilitating Partner,

- sign off on the community development plan and subproject proposal(s) before they are submitted to NSP for appraisal of technical quality, financial feasibility, and inclusive community involvement in planning and decision making.

The community will:

- elect an inclusive Community Development Council and establish Project Management Committees as needed for sub-projects;

- develop a Community Development Plan (including priority sub-project proposals with budgets and community cost contributions and O\&M arrangements);

- obtain inputs and endorsement from the community (if necessary through separate meetings with men and women) regarding the Community Development Plan;

- mobilize the required technical expertise to help develop designs within given technical standards; ${ }^{20}$

- agree on rules for dissemination of budget and expenditure information;

- submit the community development plan and proposal(s) to NSP.

As previously stated, the Facilitating Partners will have flexibility in the choice of the facilitation methodology for undertaking the activities listed above.

\section{B. Appraisal}

20 This may involve getting the required technical assistance from the market (payment can be made direct as part of the community contribution, or retroactively if and when a project is appraised and found eligible for funding), or getting this assistance from the Facilitating Partner, where it is unavailable in the market. 
The community (with the assistance of the Facilitating Partner) will complete and submit a community development plan and sub-project proposal(s) (including technical designs and cost schedules) to the provincial representative of the NSP (See Annex 1).

Appraisal of the community proposal and budget are conducted by the NSP. The Facilitating Partner will help communities prepare and implement subproject proposals and be positioned as "allies" of the community, while the NSP staff will formally appraise proposals and make funding decisions.

The NSP will be responsible for appraisal of all community project proposals to determine whether they meet the eligibility criteria. This will be done using of a standard appraisal tool (See Annex 2) by the NSP technical staff from the provincial office (and involving relevant government agencies, e.g. for health and education). The appraisal will be done using a transparent scoring procedure. Eligibility criteria, indicators and means of verification are listed in the table below. The criteria will be made known to the community in order to limit the discretionary power of the NSP. A proposal is evaluated based on these criteria and assessed during a field visit to the community. The community is then informed by the NSP regarding the result of the appraisal, which may either be approval of funding for the proposed plan, or a rejection requiring the community to revise its proposal with regard to either the election of the Community Development Council, the planning process, the budget, or the technical standards. For approved proposals, the letter will also confirm the registration of the Development Council with MRRD. Copy of this letter will be sent to the Facilitating Partner. (Annex 3).

The national level NSP office will undertake periodic field supervision audits on a sample basis of the appraisal process to ensure that eligibility criteria are complied with (Annex 4).

\section{ELIGIBILITY CRITERIA}

\begin{tabular}{|c|c|c|c|c|}
\hline $\begin{array}{l}\text { Core } \\
\text { Principles }\end{array}$ & $\begin{array}{l}\text { Eligibility } \\
\text { Criteria }\end{array}$ & Indicator & $\begin{array}{l}\text { Means of } \\
\text { Verification }\end{array}$ & $\begin{array}{l}\text { Weight } \\
\text { Assign } \\
\text { ed }\end{array}$ \\
\hline $\begin{array}{l}1 . \\
\text { Representat } \\
\text { ivecommuni } \\
\text { ty } \\
\text { institution }\end{array}$ & $\begin{array}{l}\text { Establishment } \\
\text { of a community } \\
\text { wide decision } \\
\text { making process } \\
\text { and election of } \\
\text { a } \\
\text { representative } \\
\text { Development } \\
\text { Council }\end{array}$ & 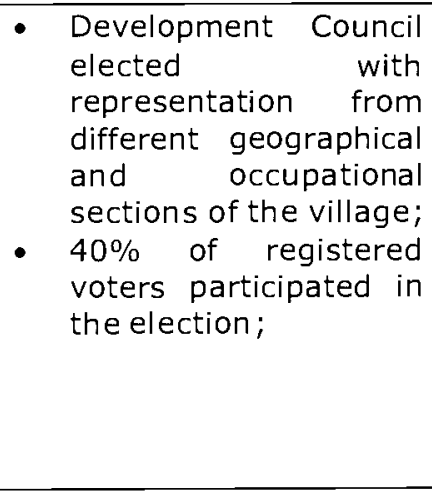 & $\begin{array}{l}\text { - } \text { Minutes of } \\
\text { community } \\
\text { meetings; } \\
\text { - Voter's register } \\
\text { and list of votes } \\
\text { cast; } \\
\text { - Random sample } \\
\text { survey of } \\
\text { villagers, } \\
\text { DC registration } \\
\text { certificate; first } \\
\text { - FP's a } \\
\text { quarterly report; }\end{array}$ & 15 \\
\hline $\begin{array}{l}2 . \\
\text { Beneficiary } \\
\text { Participatio } \\
\mathrm{n}\end{array}$ & $\begin{array}{l}\text { Community } \\
\text { Development } \\
\text { Plan endorsed } \\
\text { through a } \\
\text { community- } \\
\text { wide process }\end{array}$ & $\begin{array}{l}\text { - } \text { Community-wide } \\
\text { meetings held; } \\
60 \% \text { of families } \\
\text { participated in } \\
\text { decision meeting. } \\
\text { Decisions/priorities of } \\
\text { women taken into } \\
\text { account. }\end{array}$ & 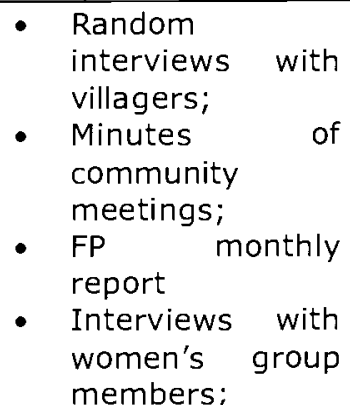 & 10 \\
\hline
\end{tabular}




\begin{tabular}{|c|c|c|c|c|}
\hline $\begin{array}{l}3 . \\
\text { Equity }\end{array}$ & $\begin{array}{l}\text { Sub-project } \\
\text { provides } \\
\text { equitable } \\
\text { access } \\
\text { benefits }\end{array}$ & $\begin{array}{l}\text { Persons from different } \\
\text { geographical and } \\
\text { occupational sections of } \\
\text { the village can access } \\
\text { benefits }\end{array}$ & $\begin{array}{l}\text { - Confirmation of } \\
\text { sub-project map } \\
\text { of beneficiaries } \\
\text { through random } \\
\text { interviews with } \\
\text { villagers }\end{array}$ & 10 \\
\hline $\begin{array}{l}4 . \\
\text { Technical } \\
\text { and } \\
\text { Financial } \\
\text { Soundness }\end{array}$ & $\begin{array}{l}\text { Sub-project is } \\
\text { technically and } \\
\text { financially } \\
\text { sound }\end{array}$ & $\begin{array}{l}\text { Sub-project complies with } \\
\text { appraisal criteria for } \\
\text { technical, financial } \\
\text { environmental and social } \\
\text { safeguards issues, and } \\
\text { the project negative list. }\end{array}$ & $\begin{array}{l}\text { Application form, } \\
\text { environmental } \\
\text { and social } \\
\text { safeguard } \\
\text { checklist, and } \\
\text { field visit }\end{array}$ & 30 \\
\hline $\begin{array}{l}5 . \\
\text { Community } \\
\text { Commitme } \\
\text { nt }\end{array}$ & $\begin{array}{l}\text { Sub-project } \\
\text { has community } \\
\text { contribution } \\
\text { towards capital } \\
\text { costs }\end{array}$ & $\begin{array}{l}\text { Minimum of } 10 \% \text { of } \\
\text { capital costs committed } \\
\text { (cash, kind or labor) }\end{array}$ & $\begin{array}{l}\text { Application form } \\
\text { Random } \\
\text { interviews with } \\
\text { villagers }\end{array}$ & 10 \\
\hline $\begin{array}{l}6 . \\
\text { Sustainabili } \\
\text { ty }\end{array}$ & $\begin{array}{l}\text { Proposed } \\
\text { project(s) has } \\
\text { community } \\
\text { arrangements } \\
\text { for operation \& } \\
\text { maintenance }\end{array}$ & $\begin{array}{l}\text { O\&M plan with budget } \\
\text { committed and training } \\
\text { plan prepared }\end{array}$ & $\begin{array}{ll}\text { - } & \text { Minutes of } \\
\text { community } \\
\text { meetings; } \\
\text { - Application form } \\
\text { Random } \\
\text { interviews with } \\
\text { villagers }\end{array}$ & 15 \\
\hline $\begin{array}{l}7 . \\
\text { Transparen } \\
\text { cy }\end{array}$ & $\begin{array}{l}\text { Accept } \\
\text { principles of } \\
\text { transparency } \\
\text { regarding } \\
\text { budgeting and } \\
\text { expenditures }\end{array}$ & $\begin{array}{llr}\text { Budget } & \text { (and later } \\
\text { accounts) posted in public } \\
\text { places and through } \\
\text { meetings (e.g. in the } \\
\text { mosque or women's } \\
\text { meetings) }\end{array}$ & 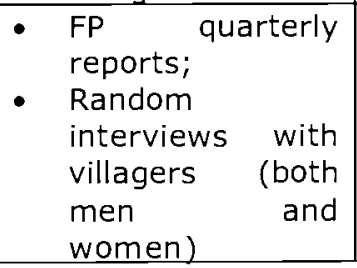 & 10 \\
\hline
\end{tabular}

\section{Tripartite Implementation Agreement}

Once the community is informed about approval of its proposal, a celebratory event will take place where the Community Development Council will sign on behalf of the community a Tripartite Implementation Agreement together with NSP officials and the Facilitating Partner.

The Implementation Agreement constitutes the contract between the community, NSP, and the Facilitating Partner, and defines the obligations and responsibilities of the parties concerning implementation of the approved Community Development Plan and subprojects (See Annex 5). It defines the block grant amount that NSP has agreed to contribute, and provides a description of the key activities to be undertaken by the different parties, as well as a time bound implementation plan for key outputs. The Implementation Agreement also defines the schedule of release of funds (tranches) for particular sub-projects depending on achievement of agreed benchmarks for implementation progress. The Implementation Agreement is signed by the members of the Community Development Council, a representative of the NSP, and the Facilitating Partner (regarding the services to be rendered by the Facilitating Partner). Addenda covering different sub-projects are signed by the nominated members of the Project Management Committee for the sub-project in question. Before the Implementation Agreement is signed, it must be explained to and understood by the community members.

The agreement covers the following: 
- Scope of activities to be covered/time frame;

- Amount of funding to be provided by NSP and terms and conditions for payments (for lump-sum payments - a set amount will be paid to the community in tranches based on outputs);

- Roles and responsibilities of all parties (the community, the Facilitating Partner, and NSP);

- Estimated amount and timeline for community contributions;

- NSP's (or representatives of MRRD's) right to inspect the site, work, materials, relevant records, accounts, and documents;

- Simple procurement and disbursement plan;

- Operation and maintenance plan;

- Clear specification of who owns the infrastructure after completion;

- NSP's right to suspend or terminate the use of funds allocated to the subproject in case of negligence and/or mismanagement;

- NSP's right to review whether possible environmental impacts have been assessed and, where necessary, to assess the adequacy of mitigation measures proposed;

- Reporting requirements (financial/physical);

- Attachments including technical designs and cost schedules.

\section{Sub-Project Implementation}

The primary responsibility for sub-project implementation will rest with the community (the Development Council, and the Project Management Committees). Clear divisions of responsibility between the Development Council members and Project Management Committee members will increase accountability. Three (or more) persons at the community level should be identified as responsible for implementation activities such as procurement, book-keeping, storage, and accounting related to a particular sub-project. This will not only promote transparency and continuity at the community level, but will also ensure that more than one person in the community has the necessary skills/training to perform the task.

Depending on the type of sub-project, the community may either be capable of undertaking implementation itself, or may require external assistance regarding specialized technical skills or services (e.g. masons for school construction, or lining and hand pump installation for dug wells for drinking water). The procurement of such services will follow established procedures (see Annex 7 on Community Bidding Formats, and Annex 8 on Community Sub-Contracting Formats).

If a community is using its block grant for more than one sub-project, parallel implementation is an option, if sufficient capacity is present, since this will speed up overall implementation, and enable completion of projects within the constraints defined by local climate and altitude.

The Facilitating Partner will support the community during this process with regard to:

- technical assistance on an as needed basis (e.g. procedures for procurement of goods or contractors);

- implementation (e.g. advice on implementation organization, and supervision of works and construction quality)

- training on matters such as book-keeping, contracting, maintenance tasks etc.

\section{E. Monitoring by the Community and Transparency}

The community wide assembly will agree on the methods and schedule of reporting to the community (on financial and physical progress) by the Community Development Council and the relevant Project Management Committees. The methods for information dissemination should ensure that women are informed about project activities. The 
community will also agree on key indicators to monitor joint decision making, project progress, and transparency. Monitoring against these indicators will be reported in the Community Progress Reporting Format used by the Facilitating Partners (Annex --).

In the community, all records and accounts must be available for inspection by the members of the community, the Facilitating Partner, and NSP. The arrangements to ensure transparency may include regular community wide information meetings, display of all relevant information on implementation progress and expenditures on notice boards accessible to the public, and/or announcements of project-related information at Jumma prayers.

\section{F. Physical and Financial Progress Monitoring}

The Facilitating Partner will be responsible for physical and financial progress monitoring on a quarterly basis (Annex --). These reports constitute an input to the overall quarterly progress reporting by NSP (Annex --). The Facilitating Partner will report to NSP on achievement of implementation benchmarks and quality of works as defined in the Implementation Agreement. Achievement of implementation benchmarks and quality of works will be tied to the release of funding to the community.

The NSP staff will perform sample audits of the work carried out by the Facilitating Partner (Annex 14).

\section{G. Subproject Completion}

A completion report will be prepared by the community and the Facilitating Partner (Annex 11). The completed project will be inspected by the NSP, and a Certificate of Completion (Annex --) will be issued to the community, provided the sub-project is technically sound and all funds received from NSP have been reconciled. NSP may approve that any savings that are remaining may be allocated to be used by the community to increase the scope of the community development plan during the current or following year.

If project funds have been fully spent, but the project has not been completed, any further funding for the community for other planned activities during year one or for activities in year two would be subject to a review by NSP.

\section{FUND FLOW AND FINANCIAL MANAGEMENT}

\section{A. Overall Fund-flow Arrangements}

The overall flow of funds to communities will be managed by the NSP. Each community development plan will include a list of priority investment needs (i.e. one or more subprojects) within the budget envelope defined by the block grant, the contribution that the community is mobilizing, and funds that can be accessed from other programs.

Each subproject proposal will be appraised individually, but implementation and funding of sub-projects can take place simultaneously, if the community has the capacity to manage this. While an overall Implementation Agreement for the community development plan (or the elements of this plan for which funding is available) will be signed between the community, NSP, and the Facilitating Partner, addendums to the Implementation Agreement will cover the specific plans and budgets for each approved subproject (Annex 5). Funds for approved subproject proposals will be channeled directly from the NSP to the community based on a tranche system of financing. 
The first tranche of funding will be released upon signing of the Implementation agreement. The tranche will be released from the NSP at central level to the provincial level NSP representative using either the banking system, where this is functioning, or a government registered Hawala. The nominated community representatives will receive the funds from the provincial representative of the NSP based upon justification (a letter of authorization from community wide forum with names and photographs plus a copy of the Implementation Agreement). A minimum of three signatories should be nominated for withdrawal of funds.

The nominated community representatives will be accompanied by the Facilitating Partner to the provincial NSP office for (at least) the first block grant disbursement. The NSP office will keep a copy of the community letter of authorization and the photos of the nominated representatives for future verification (Annex 6). Subsequent tranches to the community will be released based upon evidence of physical and financial progress of the community projects. The communities will submit expense reports and budget variance analyses on a regular, periodic basis to the Facilitating Partner. The NSP office will provide the Facilitating Partner with copies of all payment releases to communities. The final payment will be released only after NSP receives, reviews and approves the appropriate project completion report from the Facilitating Partner.

\section{B. Fund Transfer Mechanism}

The Implementation Agreement defines the schedule of disbursement tranches on the basis of an agreed plan of physical progress of a particular sub-project. Funds will be transferred using a fixed price or lump-sum method of financing. The size of individual payments under each tranche (amounts) must be determined based not only on the technical requirements of the subproject, but also on security concerns at the community level. Thus, in order to limit the amount of cash that communities will have to transport, store, and handle, the community can arrange with the NSP that specific payments are made directly at the NSP provincial office to suppliers and contractors in the presence of the community representatives.

Unless there are exceptional circumstances, payment for implementation will be made in three installments/tranches of $50 \%, 40 \%$, and $10 \%$ respectively. The first installment will be paid following signing of the Implementation Agreement, the second installment after achievement of agreed implementation outputs (benchmarks), and the third installment by or after sub-project completion supported by a financial statement. Examples of financial reporting formats and forms at the community, provincial and national levels, accompanied by explanatory text, are set out in Appendix 10.

\section{Disbursement to Communities}

The first tranche of funding will be paid to the community as soon as the Implementation Agreement based on the approved project work plan and budget is signed (see Annex on Tranche Release Format). Subsequent tranches will be released when the Facilitating Partner confirms that the physical progress benchmarks have been reached and community financial reports are in order (Annex --).

The national level NSP office will undertake periodic field supervision audits on a sample basis of the release of tranches to ensure that recommendations regarding new releases are based on the required outputs and are made on a timely basis (Annex 9 ).

The NSP contribution to the community will be specified a lump-sum contribution (tranche) for specified deliverables. Each tranche is a percentage of total subproject costs and will be based upon a disbursement plan agreed to with the community (e.g., $50 \%, 40 \%, 10 \%$ of total sub-project costs minus the value of the community contribution). A tranche is released when a specific milestone is reached and can be 
disbursed against progress reports/technical certificates. The initial payment is based on the approved sub-project proposal and is made in line with the provisions of the Implementation agreement.

In lump-sum contracts, subsequent payments are made based on physical progress reports and not on financial progress. Physical progress is certified by the Facilitating Partner representing the NSP (Annex --). In addition, the NSP will monitor physical and financial progress of subprojects on a sample basis (Annex 12). Even though release of tranches is not based on financial progress, the Community Development Council (or Project Management Committee) should be required to submit financial reports (summarizing receipts and expenditures) in order to demonstrate good accounting practice at the community level.

The formal banking system in Afghanistan is not yet sufficiently operational. The six licensed banks do not provide commercial banking services, nor do the remaining banks accept deposits not extend loans. As a stop-gap measure until the banking system is operational, the NSP will use the Hawala system to transfer money to the provincial level and to the community. To be acceptable, a money exchange dealer or Hawala that is selected to transfer funds into and around Afghanistan must be financially sound and meet the following criteria: The Hawala used to transfer funds to the provincial level must be:

- Registered with the Central Bank (Da Afghanistan Bank);

- Recognized by the Exchange Dealers Association;

- Maintain a physical presence at the Sari Shahzada in Kabul;

- Authorized to deal in foreign currencies;

- Able to issue promptly a detailed monthly statement of funds transfer transactions related to NSP;

- Work with other reputable organizations in Kabul (references), having established a satisfactory domestic and international correspondent funds transfer network; and

- Charge reasonable fees for its services.

For each Hawala transaction, good practice requires the following procedural guidelines to be observed:

- Obtain a written document confirming the amount to be transferred, currency, expected payment date, funds transfer destination and transaction fee;

- Establish transaction monetary limits based on capacity of the Hawala, security situation at origin and destination of funds, and community capacity to maintain cash holdings on their premises;

- Pay the Hawala after payment and acknowledgement of funds receipt verbally and in writing (fax or e -mail) by the intended recipient;

- Conduct all financial transactions, apart from predetermined small transactions in a secure location, preferably on the FP's or community development council's premises; and

- Restrict transfer of funds to a specific community to only one Hawala for purposes of better control and audit trail, although a Hawala may be permitted to service more than one community.

Funds will be transferred from the NSP national office through a Hawala to the NSP provincial level office, from where funds would be released to the nominated community representatives. To minimize the security risk of community members transporting, storing and managing large amount of cash, arrangements can be made, if the community so wishes, where tranches are disbursed in smaller amounts related to specific expenditures. Based on the Implementation Agreement, each tranche allocation will be known to the community, and the provincial representative of the NSP, who will 
open a ledger in the name of the community. The community would be able to draw installments from this monetary allotment to meet specific expenditures. Moreover, some payments such as those for suppliers or contractors can be made at the NSP office in the presence of the nominated community representatives authorized to handle procurement and funds.

\section{Fund Management at the Community Level}

The community project management committee will be responsible for procurement of all goods and services during the course of subproject implementation. Communities will determine the best method of payment for suppliers and contractors. Communities will be trained in simplified procurement and disbursement procedures by the Facilitating Partner based on guidelines developed by NSP. A Project Management Committee must call regular community meetings to present its financial and physical progress reports to the community, and communicate this information by other means as well (e.g. an information board, or announcements in the mosque).

The community must keep accurate financial accounts, and the Facilitating Partner shall prepare periodic financial reports. (See Annex__ for sample progress reports), The financial report provides details of funds received by the community from NSP, expenditures incurred by category and the balance of funds. All supporting documents must be kept at the community level, and be available to the Facilitating Partner, NSP, and other parties (e.g. other NSP donors or external review and evaluation consultants). Cash funds should be kept in a secure location with restricted access by a person nominated as responsible by the Community Development Council.

During implementation, the Community Development Council, together with the project management committee will undertake the following activities:

- Maintain a subproject cash book to account for all expenditures by type.

- Open and work with a checking account, check book, and bank statements, if and where the branch banking system is functioning.

- Maintain receipts, labor registers and other documentation such that all expenses have corresponding documentary evidence.

- Maintain a cash box and a petty cash book for cash expenditures.

- Maintain a stock register to record materials kept by the community (for more than one or two days) before use.

- Maintain a community contribution register to record any contribution (cash, labor, materials, etc.) from the community in the course of subproject implementation.

The project management committee should have a written record of all expenditures to back up the cash book and petty cash book. These may be in the form of receipts, labor registers, cash receipts, or other.

\section{E. Financial Management at the Facilitating Partner Level}

For presentation purposes, the roles, responsibilities, expected outputs and performance against outputs are discussed in Chapter II, Section C. The key financial reporting formats/forms submitted by the FP to the NSP are contained in Annex 10. 


\section{COMMUNITY PROCUREMENT}

Because funds for implementation of community subproject are disbursed directly to the community, the Project Management Committee(s) is primarily responsible for procuring materials, transport, labor, and contractor services. Much of the procurement relating to community-identified subprojects is usually for contracts and materials below US\$ 30,000 and is therefore carried out through direct purchase or local shopping by the communities themselves. Communities may set up rotational procurement schedules within the project management committee to ensure that no cliques form and that the committee adheres to procurement procedures.

A simple procurement plan for each sub-project should be developed by the community. The plan must take into account who will purchase goods, what will be purchased, and how. The plan should be shared with community representatives who will oversee purchases made by the project management committee as well as the community at large.

To assist communities with procurement as well as to monitor the economy of goods procured at the local level, the NSP will develop and maintain a unit cost database. The database will include costs of most types of items purchased at the community level. The database will be developed over time (using prices proposed in community budgets as well as independent research) and updated regularly. Reference price lists will be developed based on the unit cost data to assist communities negotiate prices with suppliers.

\section{A. Procurement of Materials}

All materials required for the subproject are detailed in the bill of quantities attached to the community proposal. During subproject implementation, the community financial records must clearly indicate the exact materials purchased. The following methods are frequently used by communities for purchasing materials:

Direct purchase (costs which are within a standard price list and/or less than US $\$ 500$ equivalent): Procuring directly from the supplier without getting other quotations when there is only one supplier and/or the amount is small. In order to get the best price possible, communities should check with several sources before purchasing goods, however, any supplier is acceptable as long as the price paid is at or below the standard price list effective at the time of purchase.

Local shopping (when the amount to be paid is higher than the amount included in the standard price list and for amounts equivalent or higher than US $\$ 500$ up to and including US $\$ 50,000$ equivalent): At least three quotations are obtained from suppliers and the best buy is selected. Factors such as quality, availability, and transportation costs must be taken into account. Most supplies for community subprojects are procured through local shopping. This method requires that communities obtain three quotations/bids for the purchase of materials in order to compare costs. All pro forma invoices received as a response must be maintained in the community files. This method may be used for purchasing materials that communities cannot find within the standard price list.

\section{B. Procurement of Services}

Labor: The community contribution will in most cases comprise voluntary labor. However, where the unskilled labor requirement for a particular project exceeds the amount of labor that the community is able or willing to contribute free of cost, arrangements are required so that the project pays for some of the required labor at standard market rates (around US\$1.5 per day). The needs for skilled labor such as foremen, carpenters, bricklayers, painters, electricians, and plumbers will be estimated 
before the start of subproject implementation and included in the subproject Implementation agreement. The NSP will provide standard pay rates for labor and these scales should not be exceeded. This information will be periodically updated in the unit cost database maintained by the NSP. Communities may decide whether to hire skilled labor for their subproject directly or to hire a contractor who in turn will hire the skilled labor. Regardless of who is hiring the skilled labor, preference must be given first to residents of the sub-project community.

Contractors: The community can hire construction foremen and skilled laborers themselves. If part or all of a sub-project is beyond the capacity of the community to manage, a contractor may be hired to manage the work. The community must advertise through local methods (e.g., fliers, community meetings, Jumma prayers, local newspapers, advertisements hung in public places, etc.) A community must hire a contractor only after receiving three bids (or where this is impossible, Direct Contracting may be used as described below). While a contractor's cost estimates are important elements of the selection criteria, selection should not be based solely on the lowest estimate. A contractor's technical experience must also be a key factor in the selection process. Interviews should be conducted by the community Project Management Committee together with village representatives and, if necessary, a representative of the Facilitating Partner (i.e., a technical supervisor, for example, who can help the community assess the technical quality of the contractor). Local contractors should be hired whenever possible.

(Any contract valued at greater than US $\$ 50,000$ equivalent must be awarded on the basis of National Competitive Bidding, which will be carried out with guidance from and according to NSP and World Bank procurement guidelines.).

Direct Contracting: This method is usually used where only one supplier/contractor is available locally or when the cost of using a competitive process such as local shopping is likely to be much higher relative to the value of the goods procured directly from the available source. The use of Direct Contracting must be reported by the Facilitating Partner in the quarteity progress reports to NSP.

While different options must be available to suit the varying capacities of communities, it is advisable that the community purchases materials. The contract with the contractor, meanwhile, covers labor, the contractor's fee, and specific services such as transport. The services provided by the contractor should be specified by the Project Management Committee and the breakdown of the cost given by the contractor.

\section{Storage}

Theft and waste of materials are common problems that must be addressed when securing storage space. The Project Management Committee must balance the need to buy materials in advance so as not to disrupt subproject implementation with the need for proper storage of perishable items such as cement and with security concerns. A stock record-keeping system (including designating persons responsible for stock management, record -keeping of stocks in storage, and transfers of subproject materials) should be implemented where materials are stored for more than a day, or are allocated to a contractor.

\section{Transport}

Communities often do not include transport costs in their subproject budgets. Facilitating Partner field staff working at the community level will be able to help communities get an accurate estimate of the number and size of trucks or tractor trailers needed, number of trips and distances to be traveled based on the type of subproject to 
be implemented. This information may be gathered during project preparation and used to provide guidelines on costs for transport of materials.

\section{E. Administrative Costs}

It is expected that the community will incur various administrative expenses in carrying out the subproject (e.g., stationery, travel, bank charges, etc.) Reasonable administrative, travel, and subsistence expenses for these purposes must be indicated in the community budget proposal and covered by the project.

\section{F. Savings}

Allowing communities to keep the savings promotes cost efficiency in sub-project implementation and provides an incentive for communities to negotiate better contracts and prices. When there are savings at the end of the subproject implementation, communities may use these funds to increase the scope of the community development plan. A rationale has to be provided to NSP for the use of any savings from the block grant allocation for additional project activities, and will require NSP approval.

\section{G. Transparency}

Transparency must be promoted at all levels of subproject management. Communities are required to publicize all project related information using a variety of techniques decided by the community wide assembly. Project information (amount of grant received, spent, community contributions mobilized, contractor payment information) may be communicated at community meetings, displayed on public notice boards, announced at Jumma prayers, or in local newspapers. Project Management Committees will be expected to provide financial and physical progress reports to the community on a regular basis. Community members will also be able to inspect project related accounts on a regular basis. The community may hire an internal auditor (e.g., a teacher, civil servant etc.) using subproject funds to pay for auditing of their accounts.

\section{MONITORING AND EVALUATION SYSTEM}

The NSP'S monitoring and evaluation (M\&E) system is intended to provide adequate information to the relevant stakeholders on project implementation performance, process and outcomes (see Annex - on NSP appraisal and monitoring tools). The main purpose of the monitoring system is to provide timely feedback to key stakeholders so that lessons can be learned on a real time basis and mid-course corrective action initiated where necessary. The M\&E system has four components: (i) implementation monitoring -physical/financial; (ii) process monitoring; (iii) post-implementation monitoring, including sustainability monitoring of completed sub-projects and audits; and (iv) outcome evaluation. A computerized MIS system will also be developed to ensure that information flow takes place smoothly at all levels, and is electronically processed from provincial level upwards.

Implementation monitoring: At the village level, communities will be trained by their Facilitating Partners (FPs) to monitor their own progress based on self-selected indicators (e.g. on process/participation, implementation progress, and expenditures). Simple formats will be developed for this purpose and maintained at the village/FP level. The effort would be to widely display/communicate the results of such monitoring within the village. At the next level, the Facilitating Partner, using the village as the basic unit of monitoring, will provide a comprehensive report, including physical (and other outputs) and financial progress, on a quarterly basis to the NSP -Province office (Annex -). The Facilitating Partner's report will include the findings of the community monitoring. The Facilitating Partner's quarterly progress reports will be cover the district(s) or 
province(s) in which the particular Facilitating Partner is responsible for facilitation of the NSP. Where more than one Facilitating Partner is involved in facilitation in a particular province, their reports will be aggregated at the NSP-Province level. Provincial quarterly progress reports will then be aggregated at the national level by NSP -HQ (MRRD). Cross-village and other analyses will take place at the provincial level, while crossprovincial analysis will take place at the national level. NSP-HQ will generate quarterly progress reports for the project as a whole and share with key stakeholders, including Facilitating Partners, Government of Afghanistan and external agencies like the World Bank.

Monitoring data for aggregated reporting for the provincial level will be entered into a standardized electronic MIS, and the flow of monitoring information and findings deriving from this information can be depicted as follows:

\section{Village}

(FP field staff reports to FP district and provincial management on progress and findings of community self-monitoring.

Results are communicated to the public and discussed with the with Development Council)

\section{District}

$$
\square \text { monthly or triggered }
$$

(FP district management staff process the village reports:

add comments, file one copy, forward one copy and folow-up on issues)

\section{Province}

$\square$ quarterly or triggered国

(FP Provincial office (or MRRD, if there is more than one PF in the province) inputs data from reports (including comments) into computerized MIS and generates simple province reports, by district and village. Follow-up for sites that seem to need special attention)

\section{National} quarterly

(NSP HQ inputs data into main MIS system; conducts analysis and generates national report, and comparative province and district reports)

\section{Province}

$\square$ quarterly

(public display of province data/analysis. Comparisons with other provinces and between districts within the province as a basis for discussions between FS and NSP)

\section{District} quarterly :

(public display of activity data/analysis and district comparisons; discuss $p$ rogress and problems with FP field staff)

\section{Village}

$\square$ quarterly 目

(periodic public meetings with village Development Council and community wide assembly to discuss progress and problems)

Post-implementation monitoring: The purpose here is primarily to determine whether communities are operating and maintaining their facilities in a sustainable manner. This can be carried out through a participatory sustainability monitoring exercise 3 months and 6 months after sub-projects are completed in a particular village (Annex --).

Process monitoring: Process indicators are included in the Facilitating Partners' quarterly progress report but MRRD-HQ will separately conduct, on a sample basis, a six-monthly process monitoring exercise. This will essentially involve the hiring of an external agency to spend significant time in the field to monitor key processes at the village level, make cross-village/province comparisons and suggest remedial action where required (Annex--). 
Evaluation: To evaluate project outcomes in terms of assessing whether the NSP is meeting its Program Objectives, key performance indicators have been developed (see below). Achievements against these will be reviewed on a quarterly and annual basis. In addition, a mid -term review will be conducted by the World Bank, and at the end of the project period, the World Bank will carry out an Implementation Completion Report, which focuses on evaluating whether the project objectives and targets for key performance indicators have been met.

Institutional arrangements for M\&E: The M\&E system will be managed by Facilitating Partners or MRRD at provincial level and by MRRD at the national level. While it is expected that the MRRD-Province officials will frequently make village visits, it is important to stress that senior personnel from MRRD-HQ and the NSP Steering Committee should also go to the field periodically, to get better acquainted with ground realities. MRRD-HQ will also hold quarterly meetings with Facilitating Partners to share the results of monitoring and receive feedback from them. The monitoring system will thus be periodically updated and improved, making it a live instrument for improving project performance. 
The key performance indicators against which the success of the overall NSP will be measures are listed in the matrix below:

\begin{tabular}{|c|c|c|c|}
\hline Performance Indicator & Indicator Value & Data Source & Comments \\
\hline \multicolumn{4}{|l|}{ POVERTY IMPACTS } \\
\hline Decrease in poverty level & & $\begin{array}{l}\text { Impact } \\
\text { evaluation, } \\
\text { case studies }\end{array}$ & $\begin{array}{l}\text { Mid-term } \\
\text { evaluation will } \\
\text { take place in } 2004\end{array}$ \\
\hline \multicolumn{4}{|l|}{$\begin{array}{l}\text { Community } \\
\text { Organization }\end{array}$} \\
\hline $\begin{array}{l}\text { Number of Development } \\
\text { Councils established }\end{array}$ & $\begin{array}{l}\text { Year } 1:>3,000 \\
\text { Year } 2 \text { onwards: }>\end{array}$ & MIS & \\
\hline $\begin{array}{lrr}\text { Number } & \text { of } \quad \text { villages } \\
\text { making } & \text { sub-project } \\
\text { proposals } & & \end{array}$ & $\begin{array}{l}\text { Year 1: }>3,000 \\
\text { Year } 2 \text { onwards: }>\end{array}$ & MIS & \\
\hline $\begin{array}{lr}\text { Villages with proposals } \\
\text { directly } & \text { targeting } \\
\text { women's needs }\end{array}$ & $>40 \%$ & MIS & $50 \%$ in Year 2 \\
\hline $\begin{array}{l}\text { Villages with either } \\
\text { representation of women } \\
\text { in Development Councils } \\
\text { or in separate } \\
\text { councils/committees }\end{array}$ & $>40 \%$ & MIS & $50 \%$ in Year 2 \\
\hline \multicolumn{4}{|l|}{ Service Provision } \\
\hline $\begin{array}{l}\text { Number of families } \\
\text { benefited }\end{array}$ & $\begin{array}{l}\text { Year } 1:>350,000 \\
\text { Year } 2 \text { onwards: }>\end{array}$ & MIS & \\
\hline $\begin{array}{l}\text { Number of units of } \\
\text { infrastructure built }\end{array}$ & $\begin{array}{l}\text { Year } 1:>2,500 \\
\text { Year } 2 \text { onwards: }>\end{array}$ & MIS & \\
\hline $\begin{array}{l}\text { Villages with satisfactory } \\
\text { quality of infrastructure }\end{array}$ & $>90 \%$ & Technical audit & Sample basis \\
\hline $\begin{array}{l}\text { Percentage of grants } \\
\text { disbursed }\end{array}$ & $\begin{array}{l}\text { Year } 1:>66 \% \\
\text { Year } 2 \text { onwards: }>\end{array}$ & MIS & \\
\hline \multicolumn{4}{|l|}{ Financial Management } \\
\hline $\begin{array}{l}\text { Villages allocated block } \\
\text { grants }\end{array}$ & $\begin{array}{l}\text { Year } 1:>3,000 \\
\text { Year } 2 \text { onwards: }>\end{array}$ & $\begin{array}{l}\text { Financial } \\
\text { statements } \\
\text { and MIS }\end{array}$ & \\
\hline $\begin{array}{l}\text { Village actually receiving } \\
\text { funds in timely manner }\end{array}$ & $80 \%$ & $\begin{array}{l}\text { Financial } \\
\text { statements } \\
\text { and MIS }\end{array}$ & \\
\hline $\begin{array}{l}\text { Fund utilization } \\
\text { according to milestones }\end{array}$ & $80 \%$ & $\begin{array}{l}\text { Financial } \\
\text { statements } \\
\text { and MIS }\end{array}$ & \\
\hline $\begin{array}{l}\text { Villages } \\
\text { their share of contributing } \\
\text { costs }\end{array}$ & $90 \%$ & MIS & $100 \%$ in Year 2 \\
\hline \multicolumn{4}{|l|}{ Capacity Development } \\
\hline $\begin{array}{l}\text { Number of community } \\
\text { members trained }\end{array}$ & $>9,000$ & $\begin{array}{l}\text { Training } \\
\text { database }\end{array}$ & \\
\hline $\begin{array}{l}\text { Number of FP staff } \\
\text { trained }\end{array}$ & $>2,600$ & $\begin{array}{l}\text { Training } \\
\text { database }\end{array}$ & \\
\hline $\begin{array}{l}\text { Number of MRRD staff } \\
\text { trained }\end{array}$ & $>120$ & $\begin{array}{l}\text { Training } \\
\text { database }\end{array}$ & \\
\hline \multicolumn{4}{|l|}{$\begin{array}{ll}\text { Operation } & \text { \& } \\
\text { Maintenance } & \\
\end{array}$} \\
\hline Number of community & $>6,000$ & Training & \\
\hline
\end{tabular}




\begin{tabular}{|c|c|c|c|}
\hline members trained in $O \& M$ & & database & \\
\hline $\begin{array}{l}\text { Sub-projects } \\
\text { more than } 90 \% \text { of o\&M } \\
\text { expenses are being } \\
\text { collected }\end{array}$ & $>80 \%$ & $\begin{array}{l}\text { Sustainability } \\
\text { monitoring } \\
\text { studies }\end{array}$ & $\begin{array}{l}3 \text { months and } 6 \\
\text { months after sub- } \\
\text { project completion }\end{array}$ \\
\hline
\end{tabular}

\section{FLOW OF FUNDS}
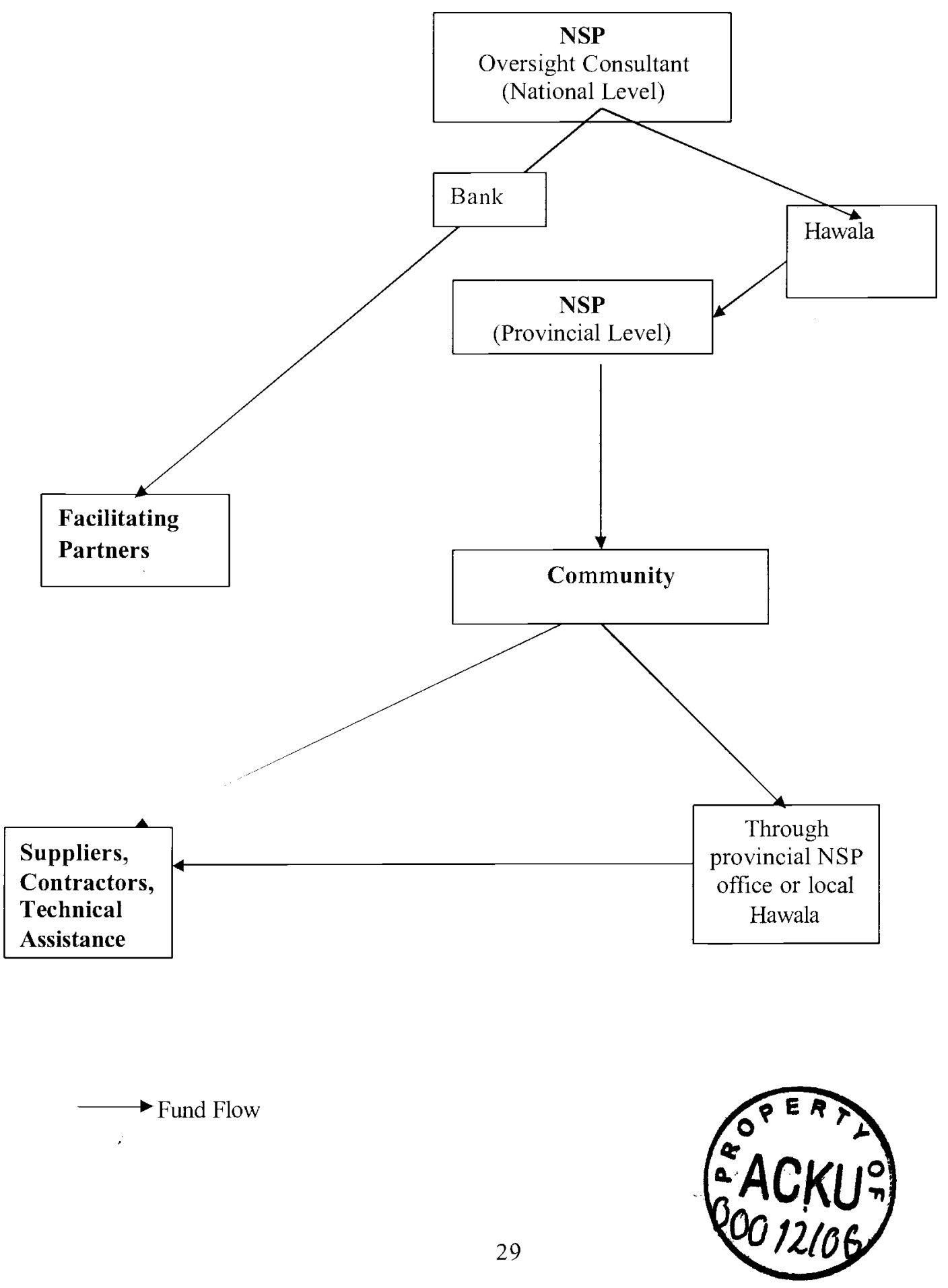
Draft December 1, 2003 